\title{
Prevalence for nematodes of hygiene-sanitary importance in fish from Colares Island and Vigia, Pará, Brasil*
}

\section{Prevalência de nematoides de importância higiênico-sanitária em peixes da ilha de Colares e Vigia, Pará, Brasil}

\author{
Marianna Vaz Rodrigues, ${ }^{* *}$ José Carlos Figueiredo Pantoja, ${ }^{* *}$ Claudio Douglas Oliveira Guimarães, ${ }^{* *}$ \\ Raimundo Nonato Moraes Benigno, ${ }^{* * *}$ Maria das Dores Correia Palha, ${ }^{* * *}$ Germano Francisco Biondi ${ }^{* *}$
}

\begin{abstract}
Zoonotic parasites can infect fish and be a serious threat to human health. The objective of this research was to estimate the prevalence for the main fish-borne zoonotic parasitic diseases of freshwater fish marketed in Colares Island and Vigia, Pará, Brazil. In February, 2012, 85 (40 of Colares and 45 of Vigia) fish were randomly sampled by means of net fishing. Eighty and $76 \%$ of fish sampled were parasitized, being silver croacker (Plagioscion squamosissimus), kumakuma (Brachyplatystoma filamentosum), and gilded catfish (Brachyplatystoma rousseauxii) the species most parasitized. The most prevalent parasites were Anisakis (50\% in Colares and $49 \%$ in Vigia) and Contracaecum (60\% in Colares and $40 \%$ in Vigia), followed by Pseudoterranova (2\% in Colares and $11 \%$ in Vigia), Eustrongylides (10\% in Colares and $0 \%$ in Vigia) and Hysterothylacium (2\% in Colares and $7 \%$ in Vigia) in the species: silver croacker, kumakuma and gilded catfish, in both cities. Mesentery (55\%) was the organ with highest level of intense infestation. A greater proportion of massive infestation was observed in females (57\%) than in males (12\%). Results of this study indicate that fish caught in Colares and Vigia could be of high risk for consumer.
\end{abstract}

Keywords: Anisakidae, Eustrongylides, zoonosis, Public Health, Amazonia.

\section{Resumo}

Parasitos zoonóticos podem infectar peixes e causar sérios agravos à saúde humana. O objetivo do presente estudo foi estimar a prevalência e identificar os fatores de risco para doenças parasitárias veiculadas por peixes de água doce comercializados na ilha de Colares e Vigia, Pará, Brazil. Em fevereiro de 2012, 85 peixes (40 de Colares e 45 de Vigia) foram coletados de forma aleatória com redes de pesca. Oitenta por cento e $76 \%$ dos peixes amostrados estavam parasitados, sendo a corvina (Plagioscion squamosissimus), piramutaba (Brachyplatystoma filamentosum) e dourada (Brachyplatystoma rousseauxii), as espécies mais parasitadas. Os parasitos mais prevalentes foram: Anisakis (50\% em Colares e 49\% em Vigia) e Contracaecum (60\% em Colares e $40 \%$ em Vigia), seguido pelo Pseudoterranova (2\% em Colares e $11 \%$ em Vigia), Eustrongylides (10\% em Colares e $0 \%$ em Vigia) e Hysterothylacium ( $2 \%$ em Colares e $7 \%$ em Vigia) nas espécies: corvina, piramutaba e dourada, em ambos os municípios. 0 mesentério (55\%) foi o órgão que apresentou infestação maciça em maior quantidade. A infestação maciça também foi observada com maior proporção em fêmeas $(57 \%)$ do que em machos (12\%). Os resultados deste estudo indicam que o peixe capturado em Colares e Vigia pode ser de alto risco para a o consumidor.

Palavras-chave: Anisakidae, Eustrongylides, zoonoses, Saúde Pública, Amazônia.

\section{Introduction}

The number of reports of fish-borne zoonotic diseases has increased as a result of several factors such as new diagnostic methods, increase of raw seafood consumption, and growth in the international market of fish (New et al., 1995; McCarthy and Moore, 2000; Chai et al., 2005; Nawa et al., 2005; Keiser and Utzinger, 2009; Robinson and Dalton, 2009).

Fish-borne zoonotic parasitic diseases include cestodes, trematodes and nematodes that infect humans by means of ingestion of contaminated raw fish. Anisakidae (nematodes) can cause allergic reactions to consumers (Ferre, 2001) and gastrointestinal perforation or obstruction (López-Serrano et al., 2000; Taniguchi et al., 2011). Anisakiasis in human is normally associated with seafood intake. The main genera involved are: Anisakis, Pseudoterranova, Hysterothylacium, and Contracaecum (Hochberg and Hamer, 2010).

The most involved species in human infection are Pseudoterranova decipiens and Anisakis simplex (EFSA, 2010). To evaluate zoonotic potential of Contracaecum, mammals were experimentally infected, resulting in damage to organism, which highlighted the zoonotic importance of this genus that belongs to Anisakidae family (Vidal-Martinez et al., 1994; Barros et al., 2004). Human infection by Eustrongylides sp. larvae has been described (Eberhard et al., 1989, Schantz, 1989; Wittner et al., 1989; Narr et al., 1996), and was characterized by abdominal pain and recovery of infectious larva from the abdomen.

\footnotetext{
*Recebido em 14 de março de 2014 e aceito em 29 de junho de 2015.

**Universidade Estadual Paulista "Júlio de Mesquita Filho".

***Universidade Federal Rural da Amazônia.

Autor para correspondência: Marianna Vaz Rodrigues - mvazrodrigues@gmail.com.
} 
Data from Fisheries and the Ministry of Aquaculture reported that Brazil is ranked $23^{\text {rd }}$ in fish production worldwide. The northern region is the most economically important in terms of continental fishery. Pará is the second most producing state $(42,082.5$ tons in 2009 and 50949 tons in 2010) (BRASIL, 2010) and fish is one the main part of the diet of many communities in the state. In view of the medical and economic importance of these data, and the scarceness of studies about fish zoonotic diseases in the region, prevalence studies of helminths of zoonotic potential would be fundamental to protect public health. The objective of this research was to estimate the prevalence for the main fishborne zoonotic parasitic diseases of freshwater fish marketed in Colares and Vigia, Pará, Brazil.

\section{Material and methods}

Colares (0055'38' S, 48'17'04' O) and Vigia (0051'47' S, $48^{\circ} 72^{\prime \prime}$ ') are located in the northeastern region of Pará and salty micro-region, with amazonic equatorial climate, having an average temperature of $26^{\circ} \mathrm{C}$ (IBGE, 2010).

In February, 2012, 40 fish of the following species: silver croacker (Plagioscion squamosissimus), ripsaw catfish (Oxydoras niger), kumakuma (Brachyplatystoma filamentosum), and gilded catfish (Brachyplatystoma rousseauxii) were randomly sampled by means of net fishing from a river in Colares. The identification of fish species were based on data published in Fish Base site (FROESE and PAULY, 2015). During the same month, 45 fish of the same species were sampled in Vigia (except for silver croacker, which was replaced by white mullet, Mugil curema, due to its absence). The distribution of fish species by city is presented in Table 1. Fish were stored in Styrofoam boxes with innocuous ice for seafood conservation and were immediately transported to the laboratory of the Universidade Federal Rural da Amazônia, in Colares Island, to perform necropsy and parasite identification.

Necropsy was performed according to the method described by Moeller Jr. (2011). The plastron was removed to visualize parasites in the abdominal cavity. Subsequently, fish were filleted to search for parasites or parasitic cysts. When parasites were found, they were removed with an anatomical clamp and stored in bottles containing ethanol, formaline, and acetic acid (AFA) at room temperature. Alive parasites were inactivated using AFA at $60^{\circ} \mathrm{C}$ (Amato et al., 1991) for further identification.

Parasites were fixed in AFA for 24 hours, preserved in alcohol $70^{\circ} \mathrm{GL}$, and clarified in lactophenol for identification according to Panesar and Beaver (1979), and Felizardo et al. (2009).

The prevalence of zoonotic parasites and fish species contaminated by Anisakis sp., Contracaecum sp., Pseudoterranova sp., Hysterothylacium sp., and Eustrongylides sp., was estimated according to Bush et al. (1997). Fish was defined as parasitized (binary variable) when at least one larva was present. Parasitic intensity (binary variable) was defined as massive when $>10$ larvae were recovered from a fish. Descriptive statistics were produced and the Chi-square or Fisher Exact test was used to test the association between prevalence of parasites and fish species, sex, affected organ or sampling location. The coexistence of parasites in the same fish was also assessed. Analyses were conducted using the $\mathrm{R}$ software version 2.14.2
(R Development Core Team, 2011). Statistical significance was defined as $P<0.05$.

\section{Results}

A total of 85 fish were sampled, from which 47 and $53 \%$ were caught in Colares and Vigia, respectively. The number and gender of fish sampled are presented in Table 1 and Figure 1. Prevalence of nematodes parasitism was not different between cities (80 and $76 \%$ in Colares and Vigia, respectively, $P=0.82$ ).

Table 1: Number of fish sampled by city studied during February 2012

\begin{tabular}{cccc}
\hline Specie & Colares & Vigia & Total \\
\hline Ripsaw catfish & 10 & 10 & 20 \\
Gilded catfish & 10 & 10 & 20 \\
Silver croacker & 10 & 0 & 10 \\
Kumakuma & 10 & 12 & 22 \\
White mullet & 0 & 13 & 13 \\
Total & 40 & 45 & 85 \\
\hline
\end{tabular}

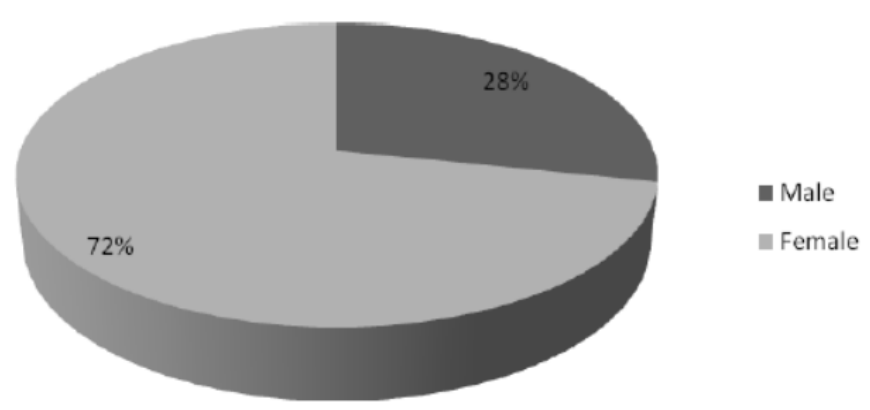

Figure 1: Prevalence of male and female sampled in Colares Island and Vigia, Pará, Brazil.

Among the species studied, the most parasitized species were silver croacker (Plagioscion squamosissimus), kumakuma (Brachyplatystoma filamentosum), and gilded catfish (Brachyplatystoma rousseauxii) (Table 2). The prevalence of each fish parasite studied can be observed in table 3. Except for Eustrongylides, the prevalence of parasitism was not different between cities.

Of the 85 fish sampled, 45\% (38/85) presented massive infestation. The most contaminated organs were the mesentery $(55 \%)$, stomach $(15 \%)$, liver $(7 \%)$, and ovary $(7 \%)$ (Table 4$)$. A greater proportion of massive infestation was observed in females $(57 \%)$ than in males $(12 \%)$, and in gilded catfish, silver croacker and kumakuma, as compared to the other species (Table 5).

The coexistence between parasites was observed for two Anisakidae genera. Of 42 fish parasitized by Anisakis, 32 (76\%) were also parasitized by Contracaecum $(P<0.01)$. The coexistence between others pairs of parasites was not significant. 
Table 2: Prevalence (\%) of each parasite found in fish species analyzed in this study

\begin{tabular}{lllllll}
\hline Species & Anisakis sp. & Contracaecum sp. & Pseudoterranova sp. & Hysterothylacium sp. & Eustrongylides sp. & Total \\
\hline Silver croacker & $10(1 / 10)$ & $70(7 / 10)$ & $0(0 / 10)$ & $0(0 / 10)$ & $10(1 / 10)$ & 10 \\
Kumakuma & $9.09(2 / 22)$ & $68.18(15 / 22)$ & $18.18(4 / 22)$ & $9.09(2 / 22)$ & $9.09(2 / 22)$ & 22 \\
Gilded catfish & $0(0 / 20)$ & $90(18 / 20)$ & $10(2 / 20)$ & $5(1 / 20)$ & $0(0 / 20)$ & 20 \\
Ripsaw catfish & $5(1 / 20)$ & $10(2 / 20)$ & $0(0 / 20)$ & $5(1 / 20)$ & $5(1 / 20)$ & 20 \\
White mullet & $0(0 / 13)$ & $0(0 / 13)$ & $0(0 / 13)$ & $0(0 / 13)$ & $0(0 / 13)$ & 13 \\
Total & 4 & 42 & 6 & 4 & 4 & 85 \\
\hline
\end{tabular}

Table 3: Prevalence of parasites detected in fish sampled in Colares and Vigia, Pará

\begin{tabular}{lcll}
\hline Parasite & Colares & Vigia & $P$-Value \\
\hline Anisakis sp. & $50 \%(20 / 40)$ & $49 \%(22 / 45)$ & 0.91 \\
Contracaecum sp. & $60 \%(24 / 40)$ & $40 \%(18 / 45)$ & 0.06 \\
Pseudoterranova sp. & $2 \%(1 / 40)$ & $11 \%(5 / 45)$ & 0.12 \\
Eustrongylides sp. & $10 \%(4 / 40)$ & $0 \%(0 / 45)$ & 0.04 \\
Hysterothylacium sp. & $2 \%(1 / 40)$ & $7 \%(3 / 45)$ & 0.36 \\
\hline
\end{tabular}

Table 4: Prevalence of intense infestation by organ evaluated in fish sampled during February 2012

\begin{tabular}{lc}
\hline Organ & Percentage of intense infestation ${ }^{1}$ \\
\hline Mesentery & $55 \%(47 / 85)$ \\
Stomach & $15 \%(13 / 85)$ \\
Liver & $7 \%(6 / 85)$ \\
Ovary & $7 \%(6 / 85)$ \\
Abdominal cavity & $5 \%(4 / 85)$ \\
Gut & $5 \%(4 / 85)$ \\
Gall bladder & $4 \%(3 / 85)$ \\
Kidney & $4 \%(3 / 85)$ \\
\hline
\end{tabular}

${ }^{1}$ Intense infestation was defined when $>10$ larvae were found in the organ.

Table 5: Association between intense infestation and local caught, sex, and fish species sampled in this study

\begin{tabular}{llc}
\hline Category & Percentage of intense infestation ${ }^{1}$ & $P$-Value \\
\hline City & 0.35 \\
Colares $^{*}$ & $50 \%(20 / 40)$ & \\
Vigia* & $40 \%(18 / 45)$ & $<0.01$ \\
Fex & & \\
Male & $57 \%(35 / 61)$ & \\
Specie & $12 \%(3 / 24)$ & \\
Ripsaw catfish & $5 \%(1 / 20)$ & \\
Gilded catfish & $85 \%(17 / 20)$ & \\
Silver croacker & $70 \%(7 / 10)$ & \\
Kumakuma & $59 \%(13 / 22)$ & \\
White mullet & $0 \%(0 / 13)$ & \\
\hline 1 Intense infestation was defined when $>10$ larvae were found in the &
\end{tabular}

${ }^{1}$ Intense infestation was defined when > 10 larvae were found in the organ.

\section{Discussion}

A high prevalence of infection by zoonotic parasites was observed in both locations studied, highlighting the importance of identifying factors that could be used to prevent the population from being exposed to such hazard. A high prevalence of zoonotic parasites (Anisakidae and Eustrongylides) was observed in silver croacker ( $P$. squamosissimus), kumakuma (B. filamentosum), and gilded catfish (B. rousseauxii), which was not reported in the literature reviewed. Previous studies have been conducted to estimate the presence of zoonotic parasites in fish marketed in the Amazon region, including the following species: aimara (Hoplerytrinus unitaeniatus), trahira (Hoplias malabaricus), red piranha (Pyogocentrus nattereri), smooth weakfish (Cynoscion leiarchus), piraputanga (Brycon micropleps), piranha (Serrasalmus marginatus), tiger catfish (Pseudoplatystoma fasciatum), flatwhiskered catfish (Pirinampus pirinampu), gilded catfish (Paulicea luetkeni), spotted sorubim (Pseudoplatystoma corruscans), south American silver croacker (Plagioscion squamosissimus), and Acestrorhynchus lacustris. The prevalence of Contracaecum sp., and Eustrongylides sp., ranged from $6.6 \%$ to $100 \%$, and $0.99 \%$ to $68.88 \%$, respectively (Barros et al., 2006; Campos, 2006; Martins et al., 2009; SilvaJunior et al., 2011; Benigno et al., 2012).

Salgado (2011) showed prevalence of 15\% (6/40) of Anisakis sp. in gilded catfish (Brachyplatystoma rousseauxii), 17.5\% (7/11) of Contracaecum sp. in peackock cichlid (Cichla spp.), and $37.5 \%$ (15/40) of Anisakis sp. in smooth weakfish (Cynoscion leiarchus) marketed in southeast of Pará. However, in the present study, a lower prevalence of Anisakis in gilded catfish (0\%) and silver croacker $(10 \%)$ was found. In contrast, the prevalence of Contracaecum sp. was $90 \%$ and $70 \%$, respectively (Table 2). Besides the presence of these parasites, Eustrongylides was also found which has zoonotic potential to the local population.

Dias et al. (2011) studied non-zoonotic species and reported a prevalence of $71.11 \%(32 / 45)$ of Poecilancistrium caryphyllum (order Trypanohryncha), in silver croacker caught in the Amazonic coast. The same authors reported that it would be necessary to perform epidemiological studies of parasitic diseases in Amazon fish, due to high levels of parasites found. This agrees with the present study because a high prevalence of massive infection was found. Massive infections can increase the risk of parasite migration to the muscles or to the abdominal cavity, which facilitates human exposure to larvae. In addition, such infections can cause significant economic losses due to condemnation of fish.

The prevalence of parasitism was highest in gilded catfish (Brachyplatystoma rousseauxii) and kumakuma (Brachyplatystoma filamentosum), and higher than that reported 
by lbiwoye et al. (2004), who found 2.6 to 4.1 larvae per fish analyzed. Regardless of the parasitic species, we found a higher prevalence of parasitism in females than in males, which disagrees with results reported by Knoff et al. (2001). These authors reported that the proportion of infected males and females depended on the parasite studied. It can be hypothesized that females were more susceptible to infection due to a possible immunosuppression caused by their reproductive status (the study was conducted during spawning). Further studies could be performed to assess the importance of sex as a risk factor for infection because control measures to protect public health could be easily implemented (e.g., selective slaughter of fish).

As to place of parasitism, the most infected organ was the mesentery, which agrees with data reported by Barros et al. (2006) and Benigno (2012). However, the presence of Eustrongylides $\mathrm{sp}$. in the oral cavity and mesentery, which was observed in this study, differs from results reported by Martins et al. (2009) and Benigno et al. (2012), which found Eustrongylides in muscle. The presence of these parasites in the oral cavity could be caused the migration from the esophagus or stomach after the death of the host, since the description by lbiwoye et al. (2004) and Urdes et al. (2008) reported the presence of this nematode only in the body cavity, gut, muscle, and external surface of internal organs such as the liver.

Regarding to parasites migration to the muscle, Karl (2008) describes that many factors can influence and the probability and time (in life and post-mortem) of Anisakidae migration from gut to the muscle. This migration can be influenced by the parasites' physiology, ecological factors, fish immunology, and biochemical alterations of post-mortem in autolysate fish. Recently, the European Food Safety Authority reported that, based on scientific evidence, migration of Anisakidae is still poorly understood (EFSA, 2010).

For parasite inactivation, freezing of seafood by seven days under $-20^{\circ} \mathrm{C}$ or $-35^{\circ} \mathrm{C}$ for 15 hours is recommended (Howgate, 2007). Huss (2004) reported that inactivation occurs below $-20^{\circ} \mathrm{C}$ for 24 hours and also emphasizes that inactivation of infective stages of parasites occurs at $55^{\circ} \mathrm{C}$ for one minute. Dias et al. (2010) and Silva-Junior et al. (2011) reported that gutting immediately after caught minimizes the probability of larvae migration to the muscle, as a function of temperature and time after fishery. However, fishermen of Colares and Vigia do not gut fish after catch, increasing the risk of migration to the muscle.

\section{Conclusion}

Results of this study indicate that fish caught in Colares and Vigia could be of high risk for human parasitism. These are important findings for supervisory agencies to guarantee the safety of fish consumption. Sanitary education campaigns and training of health agents is necessary to educate consumers and minimize the risk of infection.

\section{Acknowledgements}

The authors thank the City Council of Colares for logistical support, the Universidade Federal Rural da Amazônia (UFRA) and the Universidade Estadual Paulista (UNESP), and the Brazilian Federal Agency for the support and evaluation of graduate education (Coordenação de Aperfeiçoamento de Pessoal de Nível Superior - CAPES), and the New Frontiers National Program of Academic Cooperation (Edictal PROCAD-NF, No 21/2009) for financial support.

\section{References}

AMATO, J.F.R.; BOEGER, W.A.; AMATO, S.B. Coleta e Processamento de Parasitos de Pescado. In: Protocolos para Laboratório. Rio de Janeiro: Universidade Federal Rural do Rio de Janeiro, 1991, p. 14-32.

BARROS, L.A.; TORTELLY, R.; PINTO, R.M.; GOMES, D.C. Effects of experimental infections with larvae of Eustrongylides ignotus Jäegerskiold, 1909 and Contracaecum multipapillatum (Drasche, 1882) Baylis, 1920 in rabbits. Arquivo Brasileiro de Medicina Veterinária e Zootecnia, v. 56, n. 3, p. 325-332, 2004.

BARROS, L.A.; MORAES FILHO, J.; OLIVEIRA, R.L. Nematóides com potencial zoonótico em peixes com importância econômica provenientes do rio Cuiabá. Revista Brasileira de Ciência Veterinária, v. 13, n. 1, p. 55-57, 2006.

BENIGNO, R.N.M.; SÃO CLEMENTE, S.C.; MATOS, E.R.; MAGALHÃES PINTO, R., GOMES, D.C.; KNOFF, M. Nematodes in Hoplerytrinus unitaeniatus, Hoplias malabaricus, Pygocentrus nattereri (pisces characiformes) in Marajó Island, Brazil. Revista Brasileira de Parasitologia Veterinária, v. 21, n. 2, p. 165-170, 2012.

BUSH, A.O.; K.D. LAFFERTY; J.L. LOTZ \& A.W. SHOSTAK. Parasitology meets ecology on its own terms: Margolis et al. revisited. Journal of Parasitology, v. 83, p. 575-583, 1997.
BRASIL. Boletim Estatístico da Pesca e Aquicultura. Ministério da Pesca e Aquicultura. 2010.

CAMPOS, C.F.M. Fauna parasitária e alterações teciduais em três espécies de peixes dos rios Aquidauana e Miranda, pantanal sul mato-grossense. 2006. 116f. Dissertação (Mestrado) - Centro de Aquicultura da UNESP - Universidade Estadual Paulista "Júlio de Mesquita Filho", Jaboticabal, 2006.

CHAI, J.Y.; DARWIN MURRELL, K.; LYMBERY, A.J. Fish-borne parasitic zoonoses: status and issues. International Journal for Parasitology, v. 35, p. 1233-1254, 2005.

DIAS, F.J.E.; SÃO CLEMENTE, S.C.; KNOFF, M. Nematóides anisaquídeos e cestóides Trypanorhyncha de importância em saúde pública em Aluterus monoceros (Linnaeus, 1758) no Estado do Rio de Janeiro, Brasil. Revista Brasileira de Parasitologia Veterinária, v. 19, n. 2, p. 94-97, 2010.

DIAS, L.N.S.; PAIVA, R.S.; SÃO CLEMENTE, S.C.; RODRIGUES, A.E.; PERALTA, A.S.L.; MATOS, E.R. Cestoides de Trypanorhyncha parasitos de Scianídeos de importância comercial, capturados no Litoral Amazônico, Brasil. Revista Brasileira de Ciência Veterinária, v. 18, n. 1, p. 3-5, 2011.

EBERHARD, M.L.; HURWITZ, H.; SUN, A.; COLETTA, D. Intestinal perforation caused by larval Eustrongylides (Nematodo: Dioctophymatoidae) in New Jersey. American Society of Tropical Medicine and Hygiene, v. 40, p. 648-650, 1989. 
EUROPEAN FOOD SAFETY AUHTORITY (EFSA). Scientific Opinion on risk assessment of parasites in fishery products. EFSA Panel on Biological Hazards (BIOHAZ). European Food Safety Auhtority Journal, v. 8, n. 4, p. 1-91, 2010.

FELIZARDO, N.N.; KNOFF, M.; PINTO, R.M.; GOMES, D.C. Larval anisakid nematodes of the flounder, Paralichthys isosceles Jordan, 1890 (Pisces: Teleostei) from Brazil. Neotropical Helminthology, v. 3, n. 2, p. 57-64, 2009.

FERRE, I. Anisakiosis y otras zoonosis parasitarias transmitidas por consume de pescado. Aquatic, v. 14, p. 1-21, 2001.

FROESE, R.; PAULY, D. Editors. 2015. FishBase. World Wide Web electronic publication. www.fishbase.org, version (04/2015).

HOCHBERG, N.S.; HAMER, D.H. Anisakidosis: perils of the deep. Clinical Infectious Disease, v. 51, p. 806-812, 2010.

HOWGATE, P. 2007 Chapter 16: Parasites. Seafood Network Information Center. http://seafood.ucdavis.edu/HACCP/ Compendium/Chapt16.htm. Acessed 10 Feb 2013

HUSS, H.H. Assessment and Management of Seafood Safety and Quality. Parasites, v. 444, p. 1-229, 2004.

IBGE. 2010. Sinopse do Censo Demográfico 2010, Pará. http:// www.censo2010.ibge.gov.br/sinopse/index.php?uf=15\&dados=1. Acessed 02 May 2012.

IBIWOYE, T.I.I.; BALOGUN, A.M.; OGUNSUSI, R.A.; AGBONTALE, J.J. Determination of the infection densities of mudfish Eustrongylides in Clurias gariepinus and C. anguillaris from Bida floodplain of Nigeria. Journal of Applied Sciences and Environmental Management, v. 8, n. 2, p. 39-44, 2004.

KARL, H. Nematode larvae in fish on the German market 20 years of consumer related research. Arch Lebensmittelhyg, v. 59, p. 107-116, 2008

KEISER, J.; UTZINGER, J. Food-borne trematodiasis. Clinical Microbiological Reviews, 22:466-483, (2009).

KNOFF, M.; SÃO CLEMENTE, S.C.; PINTO, R.M.; GOMES, D.C. Nematodes of elasmobranch fishes from the coast of Brazil. Memórias do Instituto Oswaldo Cruz, v. 96, n. 1, p. 81-87, 2001.

URDES, L.; HANGAN, M.; DIACONESCU, C.; IANITCHI, D.; SERAFIM, V. Eustrongyliosis'occurrence in freshwater fish from the Danubian delta area. Zootehnie si Biotechnologii, v. 41, n. 2 , p. 182-186, 2008.

LÓPEZ-SERRANO, M.C.; GOMEZ, A.A.; DASCHNER, A.; MORENOANCILLO, A.; DE PARGA, J.M.S.; CABALLERO, M.T.; BARRANCO, P.; CABAÑAS, R. Gastroallergic anisakis: Findings in 22 patients. Journal of Gastroenterology and Hepatology, v. 15 , p. 503-506, 2000.

MARTINS, M.L.; SANTOS, R.S.; MARENGONI, N.G.; TAKAHASHI, H.K.; ONAKA, E.M. Seasonality of Eustrongylides sp. (Nematoda: Dioctophymatidae) larvae in fishes from Paraná River, South-Western Brazil. Boletim do Instituto de Pesca, v. 35, n. 1 , p. $29-37,2009$.
McCARTHY, J.; MOORE, T.A. Emerging helminth zoonoses. International Journal for Parasitology, v. 30, p. 1351-1360, 2000.

MOELLER Jr., R.B. 2011. Fish necropsy and biopsy procedures. California Animal Health and Food Safety Laboratory System University of California. http://www.cichlid-forum.com/articles/ fish_necropsy_biopsy.php. Acessed 17 Jun 2013.

NAWA, Y.; HATZ, C.; BLUM, J. Sushi delights and parasites: the risk of fishborne and foodborne parasitic zoonoses in Asia. Clinical Infectious Disease, v. 41, p. 1297-1303, 2005.

NARR, L.L.; O'DONNELL, J.G.; LIBSTER, B.; ALESSI, P.; ABRAHAM, D. Eustrongylidiasis - a parasitic infection acquired by eating live minnows. Journal of American Osteopathic Association, v. 96, n. 7, p. 400, 1996.

NEW, D.; LITTLE, M.D.; CROSS, J. Angiostrongylus cantonensis infection from eating raw snails. New England Journal of Medicine, v. 332, p. 1105-1106, 1995.

PANESAR, T.S.; BEAVER, P.C. Morphology of the advancedstage larva of Eustrongylides wenrichi Canavan 1929, occurring encapsulated in the tissues of Amphiuma in Louisiana. Journal of Parasitology, v. 65, n. 1, p. 96-104, 1979.

R DEVELOPMENT CORE TEAM. 2011. R: A language and environment for statistical computing. $R$ Foundation for Statistical Computing, Vienna, Austria. http://www.R-project.org/. Acessed 27 Jun 2012.

ROBINSON, M.W.; DALTON, J. Zoonotic helminth infections with particular emphasis on fasciolosis and other trematodiases. Philosophical Transactions Royal Society B: Biological Sciences, v. 364, p. 2763-2776, 2009.

SALGADO, R.L. 2011. Avaliação parasitológica do pescado fresco comercializado no sudeste do Pará. PUBVET. http://www. pubvet.com.br/artigos_det.asp?artigo=878. Acessed 10 Sep 2012.

SCHANTZ, P.M. The Dangers of Eating Raw Fish. New England Journal of Medicine, v. 320, n. 17, p. 1143-1145, 1989.

SILVA-JUNIOR, A.C.S.; RAMOS, J.S.; GAMA, C.S. Parasitismo de larvas de Anisakidae em Acestronrhynchus lacustris da área de proteção ambiental do rio Curiaú, Macapá, Estado do Amapá. Revista Brasileira de Engenharia de Pesca, v. 6, n. 2, p. 1-10, 2011.

TANIGUCHI, G.; NAGAHARA, A.; MATSUMOTO, K.; RITSUNO, H.; IGUSA, Y.; SASAKI, H.; MORI, H.; BEPPU, K.; SHIBUYA T.; SAKAMOTO, N.; OSADA, T.; KAWABE, M.; TERAI, T.; OGIHARA, T.; WATANABE, S. Asymptomatic anisakiasis of the colon incidentally found by colonoscopy. Journal of Clinical Gastroenterology, v. 4:, p. 371-373, 2011.

VIDAL-MARTINEZ, V.M.; OSÓRIO-SARAIA, D.; OVERSTREET, R.M. Experimental infection of Contracaecum multipapillatum (Nematoda:Anisakinae) from México in domestic cat. Journal of Parasitology, v. 80, p. 576-579, 1994.

WITTNER, M.; TURNEY, J.W.; JACQUETTE, G.; ASH, L.R.; SALGO, M.P.; TANOWITS, H.B. Eustrongylidiasis - A Parasitic Infection Acquired by Eating Sushi. New England Journal of Medicine, v. 320, n. 17, p. 1124-1126, 1989. 